\title{
DATA MINING PEMBERIAN REWARD PADA KARYAWAN UPI CONVENTION GROUP MENGGUNAKAN NEAREST NEIGHBOR
}

\author{
Eka Praja Wiyata Mandala1), Muhammad Ridwan²) dan Dewi Eka Putri ${ }^{3)}$ \\ ${ }^{1,3}$ Teknik Informatika, Fakultas Ilmu Komputer, Universitas Putra Indonesia YPTK Padang \\ ${ }^{2}$ Manajemen, Fakultas Ekonomi dan Bisnis, Universitas Putra Indonesia YPTK Padang \\ 1,2,3 Jl. Raya Lubuk Begalung, Padang, Sumatera Barat, 25221 \\ E-mail : ekaprajawm@upiyptk.ac.id ${ }^{1)}$, muhammad_ridwan@upiyptk.ac.id ${ }^{2)}$, dewieka@upiyptk.ac.id ${ }^{3)}$
}

\begin{abstract}
ABSTRAK
Reward bisa diartikan sebagai penghargaan atau hadiah, merupakan sesuatu yang diberikan oleh perusahaan kepada karyawan dengan tujuan agar karyawan menjadi senang, bisa lebih giat bekerja, semangat dalam melakukan pekerjaan dan bisa lebih rajin dalam bekerja. Bisa dikatakan reward bisa menjadi salah satu bentuk motivasi yang dilakukan oleh perusahaan untuk meningkatkan kualitas sumber daya manusia. Penelitian ini dilakukan untuk menghasilkan sebuah sistem yang dapat membantu manajemen UPI Convention Group dalam mengambil keputusan terhadap karyawan yang berhak menerma reward. Sistem dikembangkan dengan pendekatan data mining dengan menggunakan metode nearest neighbor untuk mendapatkan nilai similarity kasus baru dengan kasus sebelumnya. Penelitian ini menggunakan 8 atribut penilaian, dimana 7 atribut merupakan prediktor yaitu kehadiran dan absensi, komunikasi interpersonal, sikap dan perilaku, rajin dantanggung jawab, memiliki inisiatif, kuantitas pekerjaan dan kerapian berpakaian serta 1 atribut merupakan keputusan reward. Keputusan yang akan diambil dari penelitian ini adalah layak atau tidaknya karyawan menerima reward. Atribut yang digunakan pada penelitian ini, dapat memberikan keakuratan dalam pemberian reward kepada karyawan karena sebagian besar dapat dinilai dari personal masing-masing karyawan. Penilaian dilakukan terhadap 75 orang karyawan tetap maupun tidak tetap setelah event selesai. Dari penilaian terhadap 75 orang karyawan yang terlibat dalam event yang sudah selesai dilakukan, dapat diperoleh karyawan yang memenuhi standar atribut penilaian dalam menerima reward, yaitu terdapat 15 orang atau sekitar $20 \%$ dari total karyawan yang dinilai. Dengan menggunakan metode nearest neighbor dapat diperoleh standar penilaian dalam pemberian reward kepada karyawan untuk setiap event yang diadakan dilihat dari kasus penilaian yang ada pada event yang dilakukan sebelumnya.
\end{abstract}

Kata Kunci: Data Mining, Nearest neighbor, Reward, Karyawan, Web

\section{PENDAHULUAN}

Setiap perusahaan pasti akan selalu menginginkan karyawannya memiliki prestasi, karena akan memberikan keuntungan yang optimal bagi sebuah perusahaan dan juga dapat meningkatkan kinerja dari perusahaan tersebut. Jadi, kelangsungan sebuah perusahaan ditentukan oleh bagaimana kinerja dari karyawannya (Wirawan, Bagia and Susila, 2019)

UPI Convention Group berada di dalam kawasan Kampus Universitas Putra Indonesia YPTK Padang yang merupakan salah satu bidang usaha penopang berjalannya kegiatan Universitas. Manajemen dari usaha ini berbeda dengan kegiatan akademik, karena mempunyai manajemen sendiri. Usaha ini merupakan bidang usaha penyedia gedung dan fasilitas yang bisa disewa untuk berbagai kegiatan, diantaranya adalah pernikahan, seminar, pertemuan, pelatihan dan lain sebagainya.

UPI Convention Center pernah dijadikan sebagai objek penelitian untuk melihat kinerja karyawan berdasarkan pemberian kompensasi, disiplin kerja dan komitmen dari karyawan tersebut. Gedung ini sudah berhasil menjadi salah satu convention center terbaik karena tingginya minat masyarakat untuk menggunakan fasilitas gedung ini untuk berbagai acara diantaranya pernikahan, seminar, bursa kerja, perpisahan sekolah dan lain sebagainya (Ridwan, 2018).

UPI Convention Center merupakan salah satu gedung yang dikelola oleh UPI Convention Group, dimana selain gedung ini, usaha ini juga mengelola satu gedung lagi yaitu UPI Exhibition Hall yang digunakan untuk kegiatan yang sama (Mandala, Ridwan and Putri, 2019).

Penelitian tentang pemberian reward telah dilakukan oleh (Sari, D. P, Rinawati, D, I, Arvianto, A \& Mujur, M, 2014) di bagian administrasi Universitas Diponegoro, menghasilkan sebuah sistem penilaian kinerja dan pemberian reward terhadap karyawan di bagian administrasi Universitas Diponegoro tersebut. Berbeda dengan penelitian yang dilakukan saat ini, metode yang digunakan untuk penilaian kinerja dan pemberian reward adalah Analytical Hierarchy Process dan Fuzzy Synthetic Decision Approach 
Dalam penelitian lain, (Susilo and Putri, 2016) melakukan penelitian tentang pemberian penghargaan di bandar udara Silampari Lubuklinggau terhadap karyawannya. Penelitian ini menghasilkan sebuah sistem pendukung keputusan yang dapat membantu pihak manajemen di bandar udara tersebut dalam menentukan karyawan yang berhak mendapat penghargaan. Pendekatan yang digunakan juga berbeda dengan penelitian yang dilakukan saat ini, yaitu menggunakan metode Composite Performance Index (CPI).

Pada penelitian lainnya tentang pemberian reward, (Dhamayanti, 2018) melakukan penelitian di Universitas Indo Global Mandiri. Reward diberikan kepada karyawan berprestasi di lingkungan universitas tersebut. Penelitian ini juga menggunakan pendekatan yang berbeda yaitu dengan menggunakan Algoritma $C 4.5$

Tujuan dari penelitian ini adalah menghasilkan sebuah alat bantu pengambilan keputusan pemberian reward kepada karyawan UPI Convention Group dengan menggunakan pendekatan data mining sehingga membantu pihak manajemen untuk bisa tepat sasaran dalam memberikan reward kepada karyawan sesuai dengan kinerja dan faktor-faktor penentu yang lainnya dari karyawan tersebut.

Jadi, pemecahan yang diusulkan untuk membantu pihak manajemen dalam memutuskan karyawan yang berhak menerima reward adalah dengan pendekatan data mining menggunakan metode Nearest neighbor.

Hasil penelitian ini yaitu sebuah aplikasi yang dikembangkan dengan menggunakan bahasa pemrograman PHP dan didukung dengan menggunakan basis data MySQL. PHP merupakan bahasa pemrograman server yang digunakan untuk pembuatan aplikasi yang berbasis web. Basis data MySQL merupakan media penyimpanan data berbasis server dan bisa menunjang kinerja PHP karena sudah disediakan fungsi-fungsi yang berhubungan dengan MySQL oleh PHP (Mandala, 2015).

\section{RUANG LINGKUP}

Dalam penelitian ini permasalahan mencakup:

1. Cakupan permasalaahan.

Banyaknya kegiatan yang diselenggarakan membuat pihak manajemen harus mempersiapkan karyawan yang tidak sedikit yang terdari dari karyawan tetap dan karyawan magang yang diundang dari SMK yang diperbantukan untuk membantu melayani setiap kegiatan dan acara. Sehingga, pihak manajemen UPI Convention Group agak kesulitan dalam pemberian reward kepada karyawan.

2. Batasan-batasan penelitian.

Penelitian ini menggunakan data semua karyawan yang terlibat dalam event yang diadakan di tempat yang dikelola UPI Convention Group yang diberikan langsung oleh manajer operasional UPI Convention Group melalui wawancara. Beberapa kriteria yang digunakan adalah : Kehadiran dan Absensi, Komunikasi Interpersonal, Sikap dan Perilaku, Rajin dan Tanggung Jawab, Memiliki Inisiatif, Kuantitas Pekerjaan dan Kerapian Berpakaian
3. Rencana hasil yang didapatkan

Penelitian ini menghasilkan aplikasi data mining yang berbasis web, yang bisa menentukan karyawan yang berhak mendapat reward berdasarkan kriteria yang digunakan.

\section{BAHAN DAN METODE}

Penelitian menggunakan beberapa referensi sebagai landasan teori, diantaranya adalah :

\subsection{Data Mining}

Data mining adalah proses penambangan data dengan ukuran besar untuk bisa mendapatkan nilai dari data tersebut. Keluaran dari proses data mining ini dapat digunakan untuk memperbaiki dalam pengambilan keputusan di masa yang akan datang (Efendi and Wibawa, 2018). Data mining sangat berhubungan dengan data, informasi dan pengetahuan. Data mining dimulai dari proses ekstraksi data menjadi informasi dan kemudian informasi diolah untuk menghasilkan pola yang diterjemahkan menjadi pengetahuan. Pengetahuan akan digunakan untuk membuat keputusan oleh pihak pimpinan (Mandala, 2016).

\subsection{Nearest neighbor}

Nearest neighbor merupakan metode klasifikasi yang digunakan untuk mengelompokkan data baru ke beberapa data terdekat (Sianturi and Sitorus, 2019). Untuk memperoleh nilai similarity dari dua kasus, diperoleh dengan menggunakan (1). (Muktiadi and Kusumadewi, 2018) :

$$
\text { Similarity }(T, S)=\frac{\sum_{i=1}^{\eta_{1}} f\left(T_{i}, S_{i}\right) x w_{i}}{w_{i}}
$$

Dimana $\mathrm{T}$ adalah kasus baru, $\mathrm{S}$ adalah kasus yang ada dalam penyimpanan, $\mathrm{n}$ adalah jumlah atribut dalam tiap kasus, $\mathrm{i}$ adalah atribut individual dari 1 sampai $\mathrm{n}$ dan wi adalah bobot fitur atribut.

\subsection{Karyawan}

Karyawan merupakan sumber daya perusahaan yang paling berharga. Kemajuan sebuah perusahaan salah satunya dilihat dan ditunjang dari kualitas karyawan yang baik (Aisyah, S, Cahyadi, A, Wijaya, B, Turnip, M, 2019). Dengan kata lain karyawan juga dapat diartikan sebagai orang yang memiliki tugas sebagai pekerja pada sebuah perusahaan atau sebuah lembaga yang melakukan kegiatan operasional di tempat kerjanya dengan adanya balas jasa berupa sejumlah uang.

\subsection{Reward}

Reward merupakan faktor yang sangat penting yang berpengaruh terhadap kepuasan kerja karyawan dan juga berpengaruh terhadap komitmen organisasi untuk memotivasi dan bekerja lebih keras lagi untuk kinerja yang lebih baik (Mahendra and Subudi, 2019).

\subsection{Metodologi Penelitian}

Kerangka penelitian dari penelitian ini terlihat pada Gambar 1 


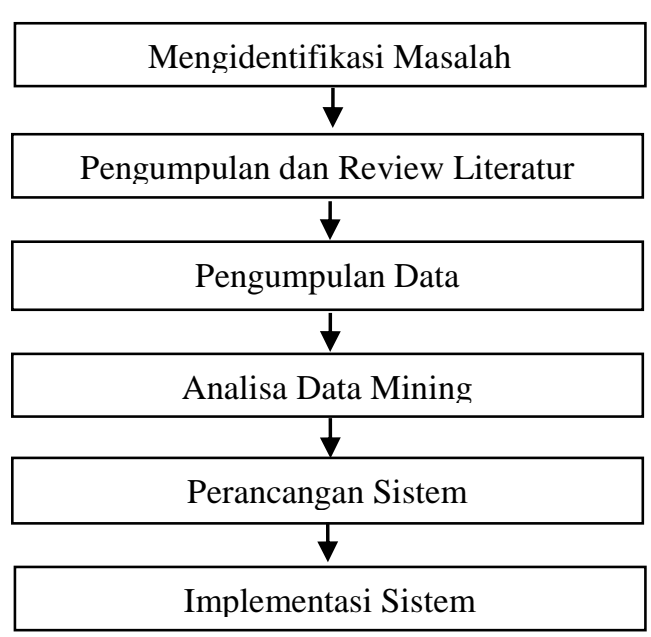

Gambar 1. Kerangka Penelitian

Dari kerangka penelitian pada Gambar 1, dapat dijelaskan masing-masing langkah kerja sebagai berikut :

1. Mengidentifikasi Masalah

Masalah diperoleh dengan melakukan observasi secara langsung pada saat ada event yang diadakan oleh UPI Convention Group. Sehingga dapat ditentukan kriteria apa saja yang bisa digunakan untuk penentuan pemberian reward.

2. Pengumpulan dan Review Literatur

Mencari dan mempelajari semua literatur yang sesuai dengan penelitian yang dilakukan buku dan publikasi dari penelitian sebelumnya tentang pemberian reward.
3. Pengumpulan Data Tabel 1

Data diperoleh dengan cara wawancara langsung dengan manajer operasional UPI Convention Group untuk mendapatkan data karyawan dan kriteria pemberian yang cocok dari manajemen usaha ini.

4. Analisa Data Mining

Data dianalisa dan diolah dengan menggunakan metode nearest neighbor menggunakan kriteria yang cocok.

5. Perancangan Sistem

Melakukan perancangan sistem dengan alat bantu perancangan yaitu diagram use case. Dilanjutkan dengan membuat prototip sistem.

6. Implementasi

Membuat aplikasi berbasis web yang bisa diakses secara client-server atau multi-tier.

\section{PEMBAHASAN}

Pada pembahasan akan dijelaskan tentang analisa, perancangan dan implementasi.

\subsection{Analisa}

Data yang digunakan dalam penelitian ini adalah data karyawan yang ada di UPI Convention Group. Data diperoleh dari hasil wawancara dengan Manajer Operasional UPI Convention Group yaitu Bapak Hendra Arsona. Wawancara dilakukan untuk memperoleh kriteria penilaian untuk penentuan pemberian reward pada karyawan. Dari hasil wawancara, dapat disimpulkan terdapat 8 atribut penilaian, dimana 7 atribut merupakan prediktor dan 1 atribut merupakan keputusan yang dapat dilihat pada Tabel 1 .

Tabel 1. Data Atribut dan Nilai Masing-Masing Atribut

\begin{tabular}{|c|c|c|}
\hline No & Atribut & Nilai Atribut \\
\hline 1 & (A) Kehadiran dan Absensi & $\begin{array}{l}\text { (A1) Tidak pernah absen dan selalu hadir tepat waktu setiap kegiatan } \\
\text { (A2) Tidak pernah absen tetapi sering terlambat } \\
\text { (A3) Sering tidak masuk dan sering terlambat kalau masuk }\end{array}$ \\
\hline 2 & (B) Komunikasi Interpersonal & $\begin{array}{l}\text { (B1) Komunikasi verbal dan non verbal sangat bagus } \\
\text { (B2) Komunikasi verbal dan non verbal bagus } \\
\text { (B3) Komunikasi verbal dan non verbal kurang bagus } \\
\text { (B4) Komunikasi verbal dan non verbal tidak bagus }\end{array}$ \\
\hline 3 & (C) Sikap dan Perilaku & $\begin{array}{l}\text { (C1) Hormat pada pimpinan, sopan dan ramah pada tamu setiap kegiatan } \\
\text { (C2) Hormat pada pimpinan, kurang sopan dan tidak ramah pada tamu setiap kegiatan } \\
\text { (C3) Tidak hormat pada pimpinan, tidak sopan dan tidak ramah pada tamu setiap kegiatan }\end{array}$ \\
\hline 4 & (D) Rajin dan Tanggung Jawab & $\begin{array}{l}\text { (D1) Mengerjakan satu pekerjaan sampai selesai dan sempurna } \\
\text { (D2) Belum selesai satu pekerjaan, pindah ke pekerjaan yang lain } \\
\text { (D3) Tidak selesai dalam mengerjakan satu pekerjaan }\end{array}$ \\
\hline 5 & (E) Memiliki Inisiatif & $\begin{array}{l}\text { (E1) Mempunyai inisiatif dan bisa mengambil tindakan untuk mengatasi masalah } \\
\text { (E2) Bisa mengatasi masalah yang terjadi saat kegiatan dilaksanakan } \\
\text { (E3) Hanya diam saja saat ada masalah }\end{array}$ \\
\hline 6 & (F) Kuantitas Pekerjaan & $\begin{array}{l}\text { (F1) Bisa menyelesaikan lebih dari satu pekerjaan } \\
\text { (F2) Hanya menyelesaikan satu pekerjaan } \\
\text { (F3) Tidak ada perkerjaan yang bisa diselesaikan }\end{array}$ \\
\hline 7 & (G) Kerapian Berpakaian & $\begin{array}{l}\text { (G1) Cara berpakaian sangat rapi } \\
\text { (G2) Cara berpakaian kurang rapi }\end{array}$ \\
\hline 8 & Keputusan Reward & \\
\hline
\end{tabular}

Tahap ini merupakan proses pemberian bobot untuk masing-masing nilai atribut yang sudah ditentukan sebelumnya. Nilai bobot juga diberikan oleh Manajer Operasional UPI Convention Group. Pemberian bobot 
sesuai dengan tingkat dari masing-masing atribut, misalnya yang terbaik akan memiliki nilai bobot lebih tinggi. Pemberian nilai bobot berada diantara rentang 0 dan 1 sesuai dengan Tabel 2.

Tabel 2. Bobot Pada Masing-Masng Atribut

\begin{tabular}{|c|l|c|}
\hline No & \multicolumn{1}{|c|}{ Atribut } & Bobot \\
\hline 1 & (A) Kehadiran dan Absensi & 0.9 \\
\hline 2 & (B) Komunikasi Interpersonal & 0.8 \\
\hline 3 & (C) Sikap dan Perilaku & 0.8 \\
\hline 4 & (D) Rajin dan Tanggung Jawab & 0.7 \\
\hline 5 & (E) Memiliki Inisiatif & 0.7 \\
\hline 6 & (F) Kuantitas Pekerjaan & 0.6 \\
\hline 7 & (G) Kerapian Berpakaian & 0.5 \\
\hline
\end{tabular}

Kedekatan nilai atribut (A) Kehadiran dan Absensi ditunjukkan pada Tabel 3.

Tabel 3. Klasifikasi (A) Kehadiran Dan Absensi

\begin{tabular}{|c|l|c|c|}
\hline No & \multicolumn{1}{|c|}{$\begin{array}{c}\text { Atribut (A) Kehadiran dan } \\
\text { Absensi }\end{array}$} & Nilai & Bobot \\
\hline 1 & $\begin{array}{l}\text { (A1) Tidak pernah absen dan } \\
\text { selalu hadir tepat waktu setiap } \\
\text { kegiatan }\end{array}$ & 100 & \multirow{2}{*}{0.9} \\
\hline 2 & $\begin{array}{l}\text { (A2) Tidak pernah absen tetapi } \\
\text { sering terlambat }\end{array}$ & 70 & \\
\hline 3 & $\begin{array}{l}\text { (A3) Sering tidak masuk dan } \\
\text { sering terlambat kalau masuk }\end{array}$ & 40 & \\
\hline
\end{tabular}

Pencarian nilai kedekatan atribut (A) Kehadiran dan Absensi yaitu dilihat pada Tabel 4.

Tabel 4. Kedekatan Nilai Atribut (A) Kehadiran Dan Absensi

\begin{tabular}{|c|c|c|c|}
\hline & A1 & A2 & A3 \\
\hline $\mathbf{A 1}$ & 1 & 0.7 & 0.4 \\
\hline $\mathbf{A 2}$ & 0.7 & 1 & 0.571 \\
\hline $\mathbf{A 3}$ & 0.4 & 0.571 & 1 \\
\hline
\end{tabular}

Kedekatan nilai atribut (B) Komunikasi Interpersonal ditunjukkan pada Tabel 5 .

Tabel 5. Klasifikasi (B) Komunikasi Interpesonal

\begin{tabular}{|c|l|c|c|}
\hline No & \multicolumn{1}{|c|}{$\begin{array}{c}\text { Atribut (B) Komunikasi } \\
\text { Interpersonal }\end{array}$} & Nilai & Bobot \\
\hline 1 & $\begin{array}{l}\text { (B1) Komunikasi verbal dan non } \\
\text { verbal sangat bagus }\end{array}$ & 100 & \multirow{2}{*}{0.8} \\
\hline 2 & $\begin{array}{l}\text { (B2) Komunikasi verbal dan non } \\
\text { verbal bagus }\end{array}$ & 70 & \multirow{2}{*}{4} \\
\hline 3 & $\begin{array}{l}\text { (B3) Komunikasi verbal dan non } \\
\text { verbal kurang bagus }\end{array}$ & $\begin{array}{l}\text { (B4) Komunikasi verbal dan non } \\
\text { verbal tidak bagus }\end{array}$ & 20 \\
\hline 4
\end{tabular}

Pencarian nilai kedekatan atribut (B) Komunikasi Interpersonal yaitu dilihat pada Tabel 6 .
Tabel 6. Kedekatan Nilai Atribut (B) Komunikasi Interpesonal

\begin{tabular}{|c|c|c|c|c|}
\hline & B1 & B2 & B3 & B4 \\
\hline B1 & 1 & 0.7 & 0.4 & 0,2 \\
\hline B2 & 0.7 & 1 & 0.571 & 0.285 \\
\hline B3 & 0.4 & 0.571 & 1 & 0.5 \\
\hline B4 & 0,2 & 0.285 & 0.5 & 1 \\
\hline
\end{tabular}

Kedekatan nilai atribut (C) Sikap dan Perilaku ditunjukkan pada Tabel 7.

Tabel 7. Klasifikasi (C) Sikap Dan Perilaku

\begin{tabular}{|c|l|c|c|}
\hline No & Atribut (C) Sikap dan Perilaku & Nilai & Bobot \\
\hline 1 & $\begin{array}{l}\text { (C1) Hormat pada pimpinan, } \\
\text { sopan dan ramah pada tamu } \\
\text { setiap kegiatan }\end{array}$ & 100 & \multirow{2}{*}{0.8} \\
\hline 2 & $\begin{array}{l}\text { (C2) Hormat pada pimpinan, } \\
\text { kurang sopan dan tidak ramah } \\
\text { pada tamu setiap kegiatan }\end{array}$ & 60 & \multirow{2}{*}{20} \\
\hline 3 & $\begin{array}{l}\text { (C3) Tidak hormat pada } \\
\text { pimpinan, tidak sopan dan tidak } \\
\text { ramah pada tamu setiap kegiatan }\end{array}$ & \multicolumn{1}{|c|}{} \\
\hline
\end{tabular}

Pencarian nilai kedekatan atribut (C) Sikap dan Perilaku yaitu dilihat pada Tabel 8 .

Tabel 8. Kedekatan Nilai Atribut (C) Sikap Dan Perilaku

\begin{tabular}{|c|c|c|c|}
\hline & C1 & C2 & C3 \\
\hline C1 & 1 & 0.6 & 0.2 \\
\hline C2 & 0.6 & 1 & 0.333 \\
\hline C3 & 0.2 & 0.333 & 1 \\
\hline
\end{tabular}

Kedekatan nilai atribut (D) Rajin dan Tanggung Jawab ditunjukkan pada Tabel 9.

Tabel 9. Klasifikasi (D) Rajin Dan Tanggung Jawab

\begin{tabular}{|c|l|c|c|}
\hline No & \multicolumn{1}{|c|}{$\begin{array}{c}\text { Atribut (D) Rajin dan } \\
\text { Tanggung Jawab }\end{array}$} & Nilai & Bobot \\
\hline 1 & $\begin{array}{l}\text { (D1) Mengerjakan satu pekerjaan } \\
\text { sampai selesai dan sempurna }\end{array}$ & 100 & \multirow{2}{*}{0.7} \\
\hline 2 & $\begin{array}{l}\text { (D2) Belum selesai satu } \\
\text { pekerjaan, pindah ke pekerjaan } \\
\text { yang lain }\end{array}$ & 60 & \multirow{2}{*}{30} \\
\hline 3 & $\begin{array}{l}\text { (D3) Tidak selesai dalam } \\
\text { mengerjakan satu pekerjaan }\end{array}$ & \\
\hline
\end{tabular}

Pencarian nilai kedekatan atribut (D) Rajin dan Tanggung Jawab yaitu dilihat pada Tabel 10.

Tabel 10. Kedekatan Nilai Atribut (D) Rajin Dan Tanggung Jawab

\begin{tabular}{|c|c|c|c|}
\hline & D1 & D2 & D3 \\
\hline D1 & 1 & 0.6 & 0.3 \\
\hline D2 & 0.6 & 1 & 0.5 \\
\hline D3 & 0.3 & 0.5 & 1 \\
\hline
\end{tabular}

Kedekatan nilai atribut (E) Memiliki Inisiatif ditunjukkan pada Tabel 11. 
Tabel 11. Klasifikasi (E) Memiliki Inisiatif

\begin{tabular}{|c|c|c|c|}
\hline No & Atribut (E) Memiliki Inisiatif & Nilai & Bobot \\
\hline 1 & $\begin{array}{l}\text { (E1) Mempunyai inisiatif dan } \\
\text { bisa mengambil tindakan untuk } \\
\text { mengatasi masalah }\end{array}$ & 100 & \multirow{3}{*}{0.7} \\
\hline 2 & $\begin{array}{l}\text { (E2) Bisa mengatasi masalah } \\
\text { yang terjadi saat kegiatan } \\
\text { dilaksanakan }\end{array}$ & 70 & \\
\hline 3 & $\begin{array}{l}\text { (E3) Hanya diam saja saat ada } \\
\text { masalah }\end{array}$ & 20 & \\
\hline
\end{tabular}

Pencarian nilai kedekatan atribut (E) Memiliki Inisiatif yaitu dilihat pada Tabel 12 .

Tabel 12. Kedekatan Nilai Atribut (E) Memiliki Inisiatif

\begin{tabular}{|c|c|c|c|}
\hline & E1 & E2 & E3 \\
\hline E1 & 1 & 0.7 & 0.2 \\
\hline E2 & 0.7 & 1 & 0.285 \\
\hline E3 & 0.2 & 0.285 & 1 \\
\hline
\end{tabular}

Kedekatan nilai atribut (F) Kuantitas Pekerjaan ditunjukkan pada Tabel 13.

\section{Tabel 13. Klasifikasi (F) Kuantitas Pekerjaan}

\begin{tabular}{|c|l|c|c|}
\hline No & \multicolumn{1}{|c|}{$\begin{array}{c}\text { Atribut (F) Kuantitas } \\
\text { Pekerjaan }\end{array}$} & Nilai & Bobot \\
\hline 1 & $\begin{array}{l}\text { (F1) Bisa menyelesaikan lebih } \\
\text { dari satu pekerjaan }\end{array}$ & 100 & \multirow{2}{*}{0.6} \\
\hline 2 & $\begin{array}{l}\text { (F2) Hanya menyelesaikan satu } \\
\text { pekerjaan }\end{array}$ & 60 & \multirow{2}{*}{20} \\
\hline 3 & $\begin{array}{l}\text { (F3) Tidak ada perkerjaan yang } \\
\text { bisa diselesaikan }\end{array}$ & \\
\hline
\end{tabular}

Pencarian nilai kedekatan atribut (F) Kuantitas Pekerjaan yaitu dilihat pada Tabel 14 .

Tabel 14. Kedekatan Nilai Atribut (F) Kuantitas Pekerjaan

\begin{tabular}{|c|c|c|c|}
\hline & F1 & F2 & F3 \\
\hline F1 & 1 & 0.6 & 0.2 \\
\hline F2 & 0.6 & 1 & 0.333 \\
\hline F3 & 0.2 & 0.333 & 1 \\
\hline
\end{tabular}

Kedekatan Nilai Atribut (G) Kerapian Berpakaian Ditunjukkan Pada Tabel 15.

Tabel 15. Klasifikasi (G) Kerapian Berpakaian

\begin{tabular}{|c|c|c|c|}
\hline No & $\begin{array}{c}\text { Atribut (G) Kerapian } \\
\text { Berpakaian }\end{array}$ & Nilai & Bobot \\
\hline 1 & (G1) Cara berpakaian sangat rapi & 100 & \multirow{2}{*}{0.5} \\
\hline 2 & (G2) Cara berpakaian kurang rapi & 40 & \\
\hline
\end{tabular}

Pencarian nilai kedekatan atribut (G) Kerapian Berpakaian yaitu dilihat pada Tabel 16 :
Tabel 16. Kedekatan Nilai Atribut (G) Kerapian Berpakaian

\begin{tabular}{|c|c|c|}
\hline & G1 & G2 \\
\hline G1 & 1 & 0.4 \\
\hline G2 & 0.4 & 1 \\
\hline
\end{tabular}

Digunakan 4 data karyawan sebagai sample data training dari 75 karyawan seperti Tabel 17 :

Tabel 17. Sampel Data Training

\begin{tabular}{|c|c|c|c|c|c|c|c|c|c|}
\hline No & $\begin{array}{c}\text { Na } \\
\text { ma }\end{array}$ & A & B & C & D & E & F & G & Reward \\
\hline 1 & A & A1 & B2 & C1 & D2 & E2 & F2 & G1 & Menerima \\
\hline 2 & B & A2 & B3 & C3 & D3 & E3 & F2 & G1 & $\begin{array}{c}\text { Tidak } \\
\text { Menerima }\end{array}$ \\
\hline 3 & C & A2 & B1 & C2 & D1 & E2 & F2 & G2 & Menerima \\
\hline 4 & D & A3 & B2 & C2 & D1 & E3 & F3 & G2 & $\begin{array}{c}\text { Tidak } \\
\text { Menerima }\end{array}$ \\
\hline
\end{tabular}

Misal, diketahui kasus baru sebagai data testing yang mempunyai nilai atribut seperti pada Tabel 18. Maka dilakukan perhitungan nilai kedekatannya dengan kasus lama pada data training di Tabel 18 .

Tabel 18. Data Testing

\begin{tabular}{|c|c|c|c|c|c|c|c|c|}
\hline No & Nama & A & B & C & D & E & F & G \\
\hline 5 & E & A2 & B2 & C1 & D2 & E1 & F1 & G2 \\
\hline
\end{tabular}

Perhitungan kedekatan kasus yang baru pada data testing Tabel 18 dengan 4 kasus yang lama pada data training Tabel 17.

1) Kedekatan kasus yang baru dengan kasus nomor 1 ditunjukkan pada Tabel 19.

Tabel 19. Perhitungan Kasus Baru Dengan Kasus Nomor 1

\begin{tabular}{|c|c|c|c|c|c|}
\hline No & $\begin{array}{c}\text { Atri- } \\
\text { but }\end{array}$ & $\begin{array}{c}\text { Kasus } \\
\text { Nomor 1 }\end{array}$ & $\begin{array}{c}\text { Kasus Baru } \\
\text { Nomor 5 }\end{array}$ & $\begin{array}{c}\text { Kede- } \\
\text { katan }(\mathbf{s})\end{array}$ & $\begin{array}{c}\text { Bobot } \\
(\mathbf{w})\end{array}$ \\
\hline 1 & A & A1 & A2 & 0.7 & 0.9 \\
\hline 2 & B & B2 & B2 & 1 & 0.8 \\
\hline 3 & C & C1 & C1 & 1 & 0.8 \\
\hline 4 & D & D2 & D2 & 1 & 0.7 \\
\hline 5 & E & E2 & E1 & 0.7 & 0.7 \\
\hline 6 & F & F2 & F1 & 0.6 & 0.6 \\
\hline 7 & G & G1 & G2 & 0.4 & 0.5 \\
\hline
\end{tabular}

Dari Tabel 19, dapat dihitung kedekatan kasus baru dengan kasus nomor 1, dengan cara :

$$
\text { Similarity }=\frac{0.63+0.8+0.8+0.7+0.49+0.36+0.2}{0.9+0.8+0.8+0.7+0.7+0.6+0.5}
$$

Similarity $=0.796$

2) Kedekatan kasus yang baru dengan kasus nomor 2 ditunjukkan pada Tabel 20 
Tabel 20. Perhitungan Kasus Baru Dengan Kasus Nomor 2

\begin{tabular}{|c|c|c|c|c|c|}
\hline No & $\begin{array}{c}\text { Atri- } \\
\text { but }\end{array}$ & $\begin{array}{c}\text { Kasus } \\
\text { Nomor 2 }\end{array}$ & $\begin{array}{c}\text { Kasus Baru } \\
\text { Nomor 5 }\end{array}$ & $\begin{array}{c}\text { Kede- } \\
\text { katan (s) }\end{array}$ & $\begin{array}{c}\text { Bobot } \\
(\mathbf{w})\end{array}$ \\
\hline 1 & A & A2 & A2 & 1 & 0.9 \\
\hline 2 & B & B3 & B2 & 0.571 & 0.8 \\
\hline 3 & C & C3 & C1 & 0.2 & 0.8 \\
\hline 4 & D & D3 & D2 & 0.5 & 0.7 \\
\hline 5 & E & E3 & E1 & 0.2 & 0.7 \\
\hline 6 & F & F2 & F1 & 0.6 & 0.6 \\
\hline 7 & G & G1 & G2 & 0.4 & 0.5 \\
\hline
\end{tabular}

Dari Tabel 20, dapat dihitung kedekatan kasus baru dengan kasus nomor 2, dengan cara :

$$
\begin{aligned}
& \text { Similarity }=\frac{0.9+0.46+0.16+0.35+0.14+0.36+0.2}{0.9+0.8+0.8+0.7+0.7+0.6+0.5} \\
& \text { Similarity }=0.513
\end{aligned}
$$

3) Kedekatan kasus yang baru dengan kasus nomor 3 ditunjukkan pada Tabel 21.

Tabel 21. Perhitungan Kasus Baru Dengan Kasus Nomor 3

\begin{tabular}{|c|c|c|c|c|c|}
\hline No & $\begin{array}{c}\text { Atri- } \\
\text { but }\end{array}$ & $\begin{array}{c}\text { Kasus } \\
\text { Nomor 3 }\end{array}$ & $\begin{array}{c}\text { Kasus Baru } \\
\text { Nomor 5 }\end{array}$ & $\begin{array}{c}\text { Kede- } \\
\text { katan (s) }\end{array}$ & $\begin{array}{c}\text { Bobot } \\
\text { (w) }\end{array}$ \\
\hline 1 & A & A2 & A2 & 1 & 0.9 \\
\hline 2 & B & B1 & B2 & 0.7 & 0.8 \\
\hline 3 & C & C2 & C1 & 0.6 & 0.8 \\
\hline 4 & D & D1 & D2 & 0.6 & 0.7 \\
\hline 5 & E & E2 & E1 & 0.7 & 0.7 \\
\hline 6 & F & F2 & F1 & 0.6 & 0.6 \\
\hline 7 & G & G2 & G2 & 1 & 0.5 \\
\hline
\end{tabular}

Dari Tabel 21, dapat dihitung kedekatan kasus baru dengan kasus nomor 3, dengan cara :

$$
\text { Similarity }=\frac{0.9+0.56+0.48+0.42+0.49+0.36+0.5}{0.9+0.8+0.8+0.7+0.7+0.6+0.5}
$$

$$
\text { Similarity }=0.742
$$

4) Kedekatan kasus yang baru dengan kasus nomor 4 ditunjukkan pada Tabel 22.

Tabel 22. Perhitungan Kasus Baru Dengan Kasus Nomor 4

\begin{tabular}{|c|c|c|c|c|c|}
\hline No & $\begin{array}{c}\text { Atri- } \\
\text { but }\end{array}$ & $\begin{array}{c}\text { Kasus } \\
\text { Nomor 4 }\end{array}$ & $\begin{array}{c}\text { Kasus Baru } \\
\text { Nomor 5 }\end{array}$ & $\begin{array}{c}\text { Kede- } \\
\text { katan (s) }\end{array}$ & $\begin{array}{c}\text { Bobot } \\
(\mathbf{w})\end{array}$ \\
\hline 1 & A & A3 & A2 & 0.571 & 0.9 \\
\hline 2 & B & B2 & B2 & 1 & 0.8 \\
\hline 3 & C & C2 & C1 & 0.6 & 0.8 \\
\hline 4 & D & D1 & D2 & 0.6 & 0.7 \\
\hline 5 & E & E3 & E1 & 0.2 & 0.7 \\
\hline 6 & F & F3 & F1 & 0.2 & 0.6 \\
\hline 7 & G & G2 & G2 & 1 & 0.5 \\
\hline
\end{tabular}

Dari Tabel 22, dapat dihitung kedekatan kasus baru dengan kasus nomor 4 , dengan cara :

$$
\text { Similarity }=\frac{0.51+0.8+0.48+0.42+0.14+0.18+0.5}{0.9+0.8+0.8+0.7+0.7+0.6+0.5}
$$

$$
\text { Similarity }=0.594
$$

Setelah ditemukan nilai similarity dari kasus nomor 5 ke masing-masing empat kasus yang lama tersebut, maka nilai similarity tertinggi adalah dengan kasus nomor 1 dengan nilai similarity 0.796 atau 79.6 yang lebih mendekati ke kasus nomor 1. Maka klasifikasi pemberian reward pada kasus nomor 5 adalah Menerima.

\subsection{Perancangan dan Implementasi}

Perancangan sistem adalah tindak lanjut dari proses analisa. Perancangan Proses perancangan sistem terlihat pada Gambar 2.

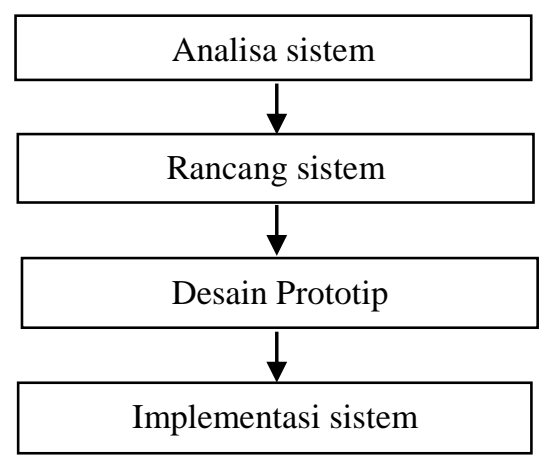

Gambar 2. Proses Perancangan Sistem

Implementasi sistem berupa hasil antar muka dari masing-masing halaman dari aplikasi data mining.

\begin{tabular}{|c|c|c|}
\hline \multirow{2}{*}{\multicolumn{3}{|c|}{$\begin{array}{l}\text { ATRIBUT dan BOBOT ATRIBUT } \\
\text { Atribut yang digunakan untuk menentukan pemberian reward pada karyawan UPI } \\
\text { Convention Group }\end{array}$}} \\
\hline & & \\
\hline No & ATRIBUT & Вовот \\
\hline 1 & (A) Kehadiran dan Absensi & 0.9 \\
\hline 2 & (B) Komunikasi Interpersonal & 0.8 \\
\hline 3 & (C) Sikap dan Perilaku & 0.8 \\
\hline 4 & (D) Rajin dan Tanggung Jawab & 0.7 \\
\hline 5 & (E) Memiliki Inisiatif & 0.7 \\
\hline 6 & (F) Kuantitas Pekerjaan & 0.6 \\
\hline 7 & (G) Kerapian Berpakaian & 0.5 \\
\hline
\end{tabular}

Hasil dari penelitian ini berupa aplikasi data mining yang akan dipakai oleh Manajer Operasional UPI Convention Group untuk menentukan karyawan yang berhak menerima reward. Nilai bobot masing-masing atribut bisa dilihat pada Gambar 3.

Gambar 3. Bobot masing-masing atribut

Gambar 3 merupakan halaman informasi bobot yang telah ditentukan. Atribut diurutkan dari bobot yang paling tinggi. Manajer Operasional UPI Convention Group bisa menentukan bobot atribut yang sudah ditentukan sebagai kriteria penilaian pemberian reward. 
Proses Nearest neighbor pemberian reward ditunjukkan pada Gambar 4:

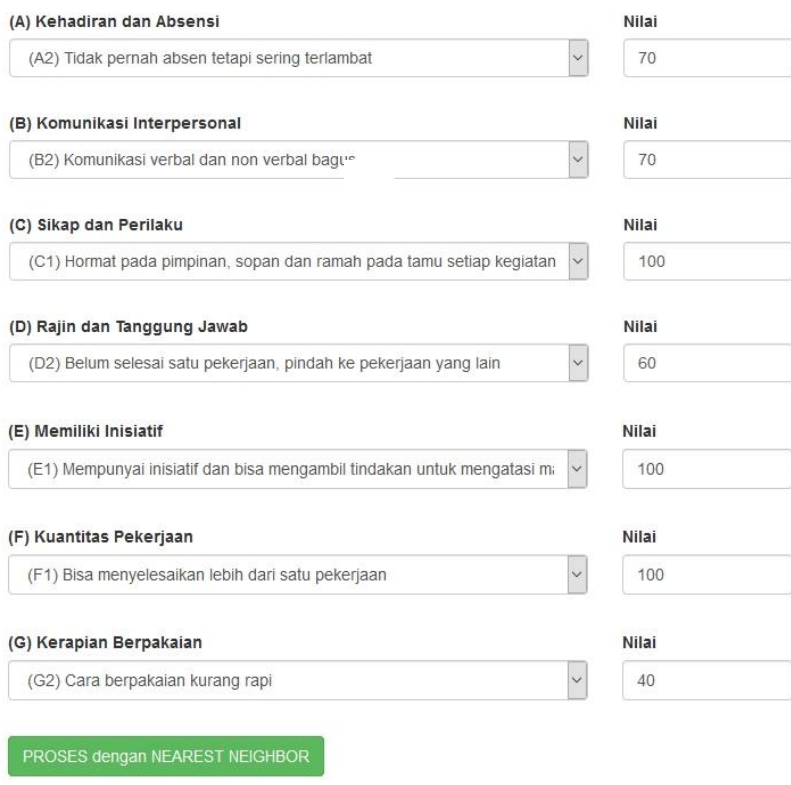

\section{Gambar 4. Proses Nearest neighbor}

Gambar 4 merupakan halaman untuk pemberian nilai pada masing-masing karyawan yang akan diberikan reward sesuai dengan komponen dari masing-masing atribut. Nilai similarity paling tinggi yang akan digunakan dalam pengambilan keputusan pemberian reward pada karyawan UPI Convention Group seperti pada Gambar 5.

HASIL NEAREST NEIGHBOR
PEMBERIAN REWARD
Untuk Karyawan UPI convention Group
Kedekatan KASUS BARU dengan KASUS NOMOR 1
0.796 atau $79.6 \%$
Kedekatan KASUS BARU dengan KASUS NOMOR 2
0.513 atau $51.3 \%$
Kedekatan KASUS BARU dengan KASUS NOMOR 3
0.742 atau $74.2 \%$

Kedekatan KASUS BARU dengan KASUS NOMOR 4
0.594 atau $59.4 \%$
MENERIMA
reward

Gambar 5. Hasil Nearest neighbor

Gambar 5 memperlihatkan hasil kedekatan kasus lama dengan kasus baru yang dimasukkan pada Gambar 4. Kasus baru dibandingkan dengan 4 kasus sebelumnya, sehingga bisa diperoleh nilai kedekatan kasusnya. Hasil perhitungan kasus baru menunjukkan bahwa kasus baru memiliki kedekatan dengan kasus 1, sehingga memiliki keputusan yang sama dengan kasus 1 yaitu Menerima.

\section{KESIMPULAN}

Penelitian ini sudah dilakukan uji coba dengan menggunakan data 75 karyawan sebagai data training yang diambil dari data karyawan yang terlibat pada event yang dilakukan sebelumnya. Data tersebut berisi data karyawan yang menerima maupun tidak menerima reward. Jumlah karyawan untuk satu event dengan event selanjutnya biasanya sama dan jarang terjadi perubahan karena karyawan tersebut sudah ditempatkan di posisi kerja masing-masing. Jadi proses testing dilakukan juga terhadap 75 orang karyawan tetap maupun tidak tetap setelah event selanjutnya selesai. Dari penilaian terhadap 75 orang karyawan yang terlibat dalam event yang sudah selesai dilakukan, dapat diperoleh karyawan yang memenuhi standar atribut penilaian dalam menerima reward, yaitu terdapat 15 orang atau sekitar $20 \%$ dari total karyawan yang dinilai. Dari sini dapat diperoleh nilai kedekatan antara kasus baru dengan kasus lama.

Penelitian ini sudah melalui beberapa tahapan sehingga sudah sampai pada tahap pengujian. Dari semua tahap yang sudah dilakukan, maka dilihat bahwa metode Nearest neighbor yang digunakan pada penelitian ini ternyata sangat membantu Manajer Operasional UPI Convention Group untuk pengambilan keputusan pemberian reward pada karyawan.

\section{SARAN}

Penelitian ini juga tidak terlepas dari kekurangan dan keterbatasan, sehingga perlu perbaikan dan pengembangan untuk kedepannya. Maka disarankan adanya penelitian lanjutan yang tidak hanya membahas pemberian reward tetapi juga membahas tentang pemberian punishment dengan penggunaan metode lainnya yang lebih tepat dan adanya penambahan fitur maupun basis aplikasi.

\section{DAFTAR PUSTAKA}

Aisyah, S. dkk. 2019. 'Aplikasi Sistem Pendukung Keputusan Analisa Kelayakan Perpanjangan Kontrak', Jurnal Sistem Informasi Ilmu Komputer Prima (JUSIKOM PRIMA), 2(2), pp. 73-76.

Dhamayanti, D. 2018. 'Penentuan Pemberian Reward Bagi Karyawan Berprestasi di Lingkungan Universitas Indo Global Mandiri dengan Algoritma C45', Jurnal Informatika Global, 9(1).

Efendi, M. S. and Wibawa, H. A. 2018. 'Prediksi Penyakit Diabetes Menggunakan Algoritma ID3 dengan Pemilihan Atribut Terbaik', JUITA: Jurnal Informatika, 6(1), pp. 29-35.

Mahendra, I. K. and Subudi, M. 2019. 'Pengaruh Iklim Organisasi Dan Sistem Reward Terhadap Kepuasan Kerja Dan Komitmen Organisasional Pada Cv. Wiracana', E-Jurnal Ekonomi dan Bisnis Universitas Udayana, 4, p. 395. doi: 10.24843/eeb.2019.v08.i04.p04.

Mandala, E. P. W. 2015. 'Web Programing, Project 1 epwm forum', Yogyakarta: Andi.

Mandala, E. P. W. 2016. 'Data Mining Algoritma 
Nearest neighbor Untuk Memprediksi Tingkat Resiko Pinjaman Dana Di Bank Perkreditan Rakyat', JIK: Jurnal Ilmu Komputer, 1(2). Available at: http://ejurnal.esaunggul.ac.id/index.php/Komp/art icle/view/1863/ (Accessed: 29 November 2018).

Mandala, E. P. W., Ridwan, M. and Putri, D. E. 2019. 'Data Mining Penilaian Kinerja Karyawan UPI Convention Group Menggunakan Bayesian Classifier', Sebatik, 23(1), pp. 53-57.

Muktiadi, R. and Kusumadewi, S. 2018. 'Sistem Pendukung Keputusan Penentuan Jenis Tindakan Preventif untuk Daerah dengan Kejadian Luar Biasa Penyakit di Kabupaten Banyumas', JUITA: Jurnal Informatika, 6(1), pp. 45-52.

Mulyadi, J. S. 2001 'Sistem perencanaan dan pengendalian manajemen', Yogyakarta: Aditya Media.

Ridwan, M. 2018. 'Analisis Pengaruh Kompensasi, Disiplin Kerja Dan Komitmen Terhadap Kinerja Karyawan Pada UPI Convention Center Padang', EKOBISTEK UPI" YPTK" PADANG, 6(1).

Sari, D. P. dkk. 2014. 'Perancangan Sistem Penilaian
Kinerja Karyawan Dan Pemberian Reward Menggunakan Analytical Hierarchy Process (Ahp) Dan Fuzzy Synthetic Decision Approach (Studi Kasus: Karyawan Administrasi Universitas Diponegoro)', J@ ti Undip: Jurnal Teknik Industri, 9(3), pp. 181-186.

Sianturi, F. A. and Sitorus, M. 2019. 'Kombinasi Metode Simple Additive Weighting (Saw) Dengan Algoritma Nearest neighbor Untuk Rekruitmen Karyawan', Jurnal Mantik Penusa, 38(2), pp. 3845.

Susilo, A. A. T. and Putri, M. A. 2016. 'Sistem Pendukung Keputusan Pemberian Reward kepada Karyawan Bandar Udara Silampari Lubuklinggau Menggunakan Metode Composite Performance Index (CPI)', Jurnal Komputer Terapan, 2(2), pp. 105-116.

Wirawan, K. E., Bagia, I. W. and Susila, G. P. A. J. 2019. 'Pengaruh Tingkat Pendidikan Dan Pengalaman Kerja Terhadap Kinerja Karyawan', Bisma: Jurnal Manajemen, 5(1), pp. 60-67. doi: 10.1016/j.jmpt.2012.06.007. 